\title{
Browsing Patterns of White-Tailed Deer Following Increased Timber Harvest and a Decline in Population Density
}

\author{
Shawn M. Crimmins, ${ }^{1,2}$ John W. Edwards, ${ }^{1}$ W. Mark Ford, ${ }^{3}$ \\ Patrick D. Keyser, ${ }^{4}$ and James M. Crum ${ }^{5}$ \\ ${ }^{1}$ Division of Forestry and Natural Resources, West Virginia University, Morgantown, WV 26506, USA \\ ${ }^{2}$ Department of Forest Management, University of Montana, Missoula, MT 59812, USA \\ ${ }^{3}$ US Geological Survey, Virginia Cooperative Fish and Wildlife Research Unit, Virginia Polytechnic Institute and State University, \\ Blacksburg, VA 24061, USA \\ ${ }^{4}$ Department of Forestry, Wildlife, and Fisheries, University of Tennessee, Knoxville, TN 37996, USA \\ ${ }^{5}$ Wildlife Resources, West Virginia Division of Natural Resources, Elkins, WV 26241, USA
}

Correspondence should be addressed to Shawn M. Crimmins, shawn.crimmins@umontana.edu

Received 14 August 2010; Accepted 14 October 2010

Academic Editor: Douglass F. Jacobs

Copyright ( $) 2010$ Shawn M. Crimmins et al. This is an open access article distributed under the Creative Commons Attribution License, which permits unrestricted use, distribution, and reproduction in any medium, provided the original work is properly cited.

\begin{abstract}
We examined browsing patterns of white-tailed deer (Odocoileus virginianus) on a site in the central Appalachians that experienced a substantial $(>50 \%)$ reduction in deer population density and an increase in the amount of timber harvest since 2001 . We sampled woody browse in and immediately adjacent to 12 clearcuts ranging in age from $0-5$ years postharvest in summer 2007. Clearcutinterior areas had higher woody browse abundance and browsing rates than clearcut-edge or mature forest areas. Woody browse abundance was slightly higher within individual clearcuts than in 2001 at higher population densities and lower timber harvest rates. Overall browsing rates declined from approximately $17 \%$ in 2001 to less than 5\% during our study, suggesting that the combination of deer population control, and increasing the amount of timber harvest across the landscape can reduce herbivory to levels that may not impede growth and survival of forest vegetation.
\end{abstract}

\section{Introduction}

Browsing by white-tailed deer (Odocoileus virginianus) has many well-documented ecological impacts in hardwood forest communities [1-3]. Intensive browsing can reduce understory forb growth rates, ground cover, and species diversity [4-7]. Likewise, woody plant diversity, growth rates, and density can be reduced by white-tailed deer browsing in forested areas $[3,8,9]$. In an examination of whitetailed deer and forest community structure, Stromayer and Warren [10] concluded that excessive deer herbivory was creating alternate steady state forests in many areas of the eastern United States. Herbivory by high density deer populations can even lead to the complete removal of plant species from forest communities that are selectively browsed [11, 12]. Moreover, the resulting effects of deer herbivory on vegetative structure also can negatively affect other forest wildlife. For example, ground-nesting songbird abundance can be reduced due to decreased density and abundance of understory vegetation [13]. McShea et al. [14] observed that Kentucky warbler (Oporornis formosus) habitat selection shifted and breeding territory establishment decreased where white-tailed deer herbivory was high. In British Columbia, areas protected from Sitka black-tailed deer (O. hemionus sitkensis) browsing had higher densities of breeding songbirds, higher insect abundance, and greater insect species diversity than areas with a history of deer browsing $[15,16]$.

Several previous studies have attempted to identify population density thresholds beyond which white-tailed deer herbivory negatively affects forest communities. In a 10-year study of herbivory in northern hardwood forests of Pennsylvania, Horsley et al. [3] found that white-tailed deer densities exceeding $8 / \mathrm{km}^{2}$ were high enough to negatively 
impact forest vegetation and affect successional dynamics and suggested that high historical densities $\left(12-23 / \mathrm{km}^{2}\right)$ led to vegetation communities with low species diversity. Likewise, deCalesta [2] found a density threshold between $7.9 / \mathrm{km}^{2}$ and $14.9 / \mathrm{km}^{2}$ above which richness and abundance of woody plant species were substantially reduced. However, such studies have typically occurred in relatively small enclosures and have not examined herbivory patterns of free-ranging white-tailed deer populations. The browsing patterns observed in such small-scale and highly controlled studies may not be representative of patterns exhibited in free-ranging populations, where resource competition and availability could vary substantially. Additionally, these studies could not assess the potential effects of landscapelevel changes in habitat structure or resource distribution, owing to their small spatial scale. Marquis et al. [17] suggested that increases in the amount of timber harvest across the landscape can buffer the impacts of herbivory from abundant white-tailed deer populations, but such effects are difficult to assess in small-scale studies conducted in enclosures such as those of deCalesta [2] and Horsley et al. [3].

In areas where white-tailed deer are considered overabundant a common management objective is to reduce population densities to minimize negative effects of herbivory on forest plant communities or other ecosystem components [4]. However, very little information exists on the browsing patterns of free-ranging white-tailed deer herds at low population densities (e.g., $<5 / \mathrm{km}^{2}$ ). In the eastern United States, most contemporary studies assessing browsing patterns of free-ranging white-tailed deer have occurred in areas where deer population densities exceed the thresholds beyond which herbivory can limit the growth of forest vegetation $[2,3,18,19]$. These studies have also failed to account for changes in landscape and habitat structure that might be expected to occur in areas with sustained timber harvest. To date, no studies have provided comparative information on browsing rates of free-ranging populations in response to density reduction or changes in the amount of timber harvest across the landscape. Alverson et al. [4] suggested that deer densities $<4 / \mathrm{km}^{2}$ are necessary to maintain plant diversity in northern hardwood or mixed-forest systems. However, they acknowledge that there is limited empirical support for this argument and that research on such populations is necessary to determine if or where thresholds of deer density exist with respect to browsing rates. Understanding browsing patterns of free-ranging white-tailed deer herds at varying population densities, particularly at low densities, is thus critical for effective forest management $[18,20,21]$. Our objective was to examine the availability and use of woody browse species in and adjacent to regenerating clearcuts (0-5 years post harvest) in an area that recently experienced a substantial decline in white-tailed deer densities and a concomitant increase in the amount of timber harvest. We hypothesized that, because either a reduction in population density or an increase in the amount of early successional area would lead to decreased browsing pressure, the combination of the two would result in substantially lower browsing rates than previously found on our study site when population densities were approximately three times higher and the amount of early successional area across the landscape was lower.

\section{Materials and Methods}

2.1. Study Area. We examined browse use and availability on the MeadWestvaco Wildlife and Ecosystem Research Forest (MWERF) in central Randolph County, West Virginia during the summer of 2007. The 3,260-ha MWERF occurs in the Unglaciated Allegheny Mountain and Plateau physiographic province [22] and ranges in elevation from approximately 700 to 1200 meters. The MWERF is characterized by steep slopes, broad ridge-tops and narrow valleys with small, highgradient headwater streams. Average annual precipitation on the site ranges from 170 to $190 \mathrm{~cm}$ with an average snowfall $>300 \mathrm{~cm} /$ year. The MWERF was originally harvested in the early 1900's and is comprised primarily of second-growth northern hardwood forests [23]. Forest communities of the MWERF were dominated by red maple (Acer rubrum), sugar maple (Acer saccharum), yellow-poplar (Liriodendron tulipifera), and black cherry (Prunus serotina). Other common associates included northern red oak (Quercus rubra), yellow birch (Betula allegheniensis), American beech (Fagus grandifolia), Fraser magnolia (Magnolia fraseri), and American basswood (Tilia americana). Highest elevations contained red spruce (Picea rubens) and eastern hemlock (Tsuga canadensis) communities. Throughout much of the area, the understory is dominated by greenbrier (Smilax spp.) and mountain laurel (Kalmia latifolia), with dense rosebay rhododendron (Rhododendron maximum) prevalent along riparian areas. Since 2000, more than 500 ha of forest have been harvested on the MWERF, with $75 \%$ using clearcutting for harvest and regeneration, and the remaining 25\% in deferment and marked-selection harvests. Even-aged harvests have averaged 15 ha in size since the mid-1990's.

2.2. Changes in Population Density and Landscape Structure. We used a distance sampling approach to estimate whitetailed deer population densities on the MWERF [24]. We conducted four population surveys between October 2005 and October 2007 along a predetermined $35 \mathrm{~km}$ survey route that provided adequate spatial coverage of the study site. Population density estimates from individual surveys ranged from $1.2 / \mathrm{km}^{2}$ (95\% CI $\left.0.4-4.1\right)$ to $2.6 / \mathrm{km}^{2}(95 \%$ CI 1.1-5.7). Similar methods were used during four surveys conducted between August 2000 and May 2001 [25]. Density estimates from these previous surveys ranged from $8.3 / \mathrm{km}^{2}$ (95\% CI $6.8-10.0)$ to $10.7 / \mathrm{km}^{2}$ (95\% CI $\left.8.2-13.8\right)$ [25], representing a decrease in population density of $>50 \%$. This decrease in population density is primarily the result of research activities, which led to the removal of 100 animals between 2002 and the time of our study ([26] S. Crimmins unpublished data). Additionally, increases in predator populations throughout the region may have limited deer recruitment, as both coyotes (Canis latrans) and black bears (Ursus americanus) are known to prey upon deer neonates 
in the region [27]. This combination of factors appears to have caused substantial declines in population density observed between 2001 and the time of our study and provided a unique opportunity to assess the potential effects of population decline on herbivory patterns in a retrospective manner. A study of herbivory patterns on the MWERF also was conducted in 2001 [19], providing comparative data for browsing rates at high population densities. Additionally, approximately $7 \%$ of the study site comprised clearcuts 0 5 years postharvest in 2001, which increased to $>12 \%$ at the time of our study. Herbivory studies conducted between 2002 and 2004 provide additional comparative data on browsing rates $[26,28]$.

2.3. Data Collection. We selected 12 clearcuts ranging in age from $0-5$ years post-harvest to examine availability and use of woody browse by white-tailed deer in summer 2007 . Clearcuts were randomly selected from across the study area. We defined age classes based on the number of complete growing seasons (years) since harvest [19]. Using methods similar to those from other studies of white-tailed deer herbivory in the region $[18,19]$, we systematically established 15 pairs of $0.5-\mathrm{m}^{2}$ plots at $50-\mathrm{m}$ intervals, with one plot from each pair placed within the interior of each clearcut and the other plot from each pair placed in the adjacent mature forest. Both plots were placed $20-\mathrm{m}$ from the clearcut edge. Using a random starting point along the clearcut edge, this design provided adequate coverage of the clearcuts and surrounding mature forest. To examine differences in browse use and availability between the clearcut edge and interior, we established an additional plot between each pair of clearcut interior and mature forest plots 5-m into the clearcut. Thus, for each clearcut we measured woody browse abundance and use in 45 plots ( 15 clearcut interior, 15 clearcut edge, 15 mature forest). Within each plot, we identified all woody species and quantified the number of woody twig tips available for browsing (i.e., $\leq 1.5 \mathrm{~m}$ from the ground) by species group following Ford et al. [18]. We calculated percent of available twigs browsed (PATB), relative abundance (RA), and relative use (RU) for each species following Strole and Anderson [29] as PATB = (number of twigs browsed for a species/number of twigs available for a species) $* 100, \mathrm{RA}=$ (number of twigs available for a species/number of twigs available for all species) $* 100$, and $\mathrm{RU}=$ (number of twigs browsed for a species/total number of twigs browsed for all species) $* 100$.

2.4. Statistical Analyses. We compared total woody browse abundance among plot types (i.e., clearcut interior, clearcut edge, mature forest) using analysis of variance (ANOVA). Our ANOVA model included plot type $(n=3)$ as a treatment effect. We used Tukey's honestly significant difference (HSD) as a multiple range test for post-hoc comparisons [30]. We compared PATB among plot types for each species and across all species using pairwise chi-square tests with a Bonferroni correction to maintain experimentwise error rates [31]. We determined browsing selection for individual species across plot types using chi-square tests between the binomial probabilities of relative use and relative abundance for each species [30]. We assigned species as browsed at rates greater than, less than, or equal to available if relative use values were higher, lower, or statistically equal to relative abundance values. All statistical tests were conducted using SAS (Statistical Analysis Systems Institute, 2001) with $\alpha=0.10$.

2.5. Comparison to Previous Studies. We examined changes in woody browse abundance and use relative to deer population density and timber harvest rates by comparing our results to data collected in 2001 prior to population decline or increasing timber harvest [19]. These data included plot level estimates of woody browse abundance and PATB for both mature forest and clearcut interior plots collected at known population densities $[19,25]$.

\section{Results}

3.1. Browse Abundance. Total woody browse abundance for all species differed by plot type $(F=63.31, P<.001)$ with mature forest plots producing less woody browse than clearcut interior or clearcut edge plots and clearcut interior plots producing the most among the three plot types (Table 1). Most species or species groups were least abundant in mature forest plots with the exception of striped maple (Acer pennsylvanicum, $F=33.48, P<.001$ ), sugar maple $(F=17.84, P<.001)$, red maple $(F=17.87, P<.001)$, and American beech $(F=4.55, P=.011)$. Of the 15 species and species groups recorded, only greenbrier $(F=1.74, P=.176)$, blackgum (Nyssa sylvatica, $F=1.73, P=.178$ ), and eastern hemlock $(F=0.45, P=.64)$ did not differ in abundance among plot types.

3.2. Browse Use and Selection. Percent of available twigs browsed (PATB) was similar between clearcut-interior and mature-forest plots $(P=.388)$ but was significantly higher $(P<.001)$ in clearcut-edge plots than in either mature-forest or clearcut-interior plots (Table 1). Browsing rates of individual species varied substantially among plot types (Table 1). With the exception of yellow-poplar, sugar maple, and red maple, all species and species groups had highest PATB values in clearcut-edge or mature-forest plots (Table 1). Of the 15 species and species groups, 5 were browsed at rates equal to their availability when pooled across plot types (Table 2). Blackberry (Rubus spp., $P<.001$ ), yellow birch $(P<.001)$, pin cherry (Prunus pennsylvanica, $P<.001$ ), sassafras (Sassafras albidum, $P<.001$ ), American beech $(P=.026)$ and blackgum $(P=.034)$ were browsed at rates higher than their respective availabilities. Greenbrier $(P<.001)$, yellow-poplar $(P<.001)$, and striped maple $(P=.013)$ were browsed at rates lower than their respective availabilities. There was moderate evidence to suggest that the "other" species group was also browsed at a rate lower than its availability $(P=.071)$.

3.3. Changes in Browse Abundance and Use. Our estimates of browse abundance were moderately higher than previously 
TABle 1: Mean (SE) availability and use of woody browse species in clearcut interior, clearcut edge, and mature forest plots on the MeadWestvaco Wildlife and Ecosystem Research Forest, Randolph County, West Virginia during summer 2007.

\begin{tabular}{|c|c|c|c|c|c|c|}
\hline \multirow[b]{2}{*}{ Species } & \multicolumn{2}{|c|}{ Clearcut interior $^{\mathrm{a}}$} & \multicolumn{2}{|c|}{ Clearcut edge $^{\mathrm{a}}$} & \multicolumn{2}{|c|}{ Mature forest $\mathrm{a}^{\mathrm{a}}$} \\
\hline & $\begin{array}{c}\text { Available } \\
\text { (twigs } / 0.5 \mathrm{~m}^{2} \text { ) }\end{array}$ & $\begin{array}{c}\text { Use }^{\mathrm{c}} \\
\text { (PATB) }\end{array}$ & $\begin{array}{c}\text { Available }{ }^{\mathrm{b}} \\
\text { (twigs } / 0.5 \mathrm{~m}^{2} \text { ) }\end{array}$ & $\begin{array}{c}U_{s e}^{c} \\
\text { (PATB) }\end{array}$ & $\begin{array}{c}\text { Available } \\
\text { (twigs } / 0.5 \mathrm{~m}^{2} \text { ) }\end{array}$ & $\begin{array}{c}\text { Use }^{c} \\
\text { (PATB) }\end{array}$ \\
\hline Blackberry (Rubus spp.) & $22.04(2.24) \mathrm{A}$ & $4.18 \mathrm{a}$ & $12.56(1.51) \mathrm{B}$ & $6.80 \mathrm{~b}$ & $0.11(0.07) \mathrm{C}$ & $0.00 \mathrm{ab}$ \\
\hline Birch (Betula spp.) & $6.81(1.04) \mathrm{A}$ & $4.57 \mathrm{a}$ & $5.20(0.91) \mathrm{A}$ & $8.33 \mathrm{~b}$ & $0.44(0.13) \mathrm{B}$ & $10.00 \mathrm{~b}$ \\
\hline Black cherry (Prunus serotina) & $4.12(0.81) \mathrm{A}$ & $3.51 \mathrm{a}$ & $1.69(0.45) \mathrm{B}$ & $4.93 \mathrm{a}$ & $0.25(0.10) \mathrm{B}$ & $0.00 \mathrm{~b}$ \\
\hline Greenbrier (Smilax spp.) & $3.77(0.85) \mathrm{A}$ & $0.89 \mathrm{a}$ & $5.74(0.75) \mathrm{A}$ & $1.45 \mathrm{ab}$ & $5.53(0.96) \mathrm{A}$ & $1.65 \mathrm{~b}$ \\
\hline Yellow-poplar (Liriodendron tulipifera) & $2.77(0.43) \mathrm{A}$ & $0.40 \mathrm{a}$ & $0.76(0.17) \mathrm{B}$ & $0.00 \mathrm{a}$ & $0.28(0.11) \mathrm{B}$ & $0.00 \mathrm{a}$ \\
\hline Pin cherry (Prunus pennsylvanica) & $2.33(0.56) \mathrm{A}$ & $6.90 \mathrm{a}$ & $1.66(0.53) \mathrm{A}$ & $7.72 \mathrm{a}$ & $0.09(0.06) \mathrm{B}$ & $0.00 \mathrm{~b}$ \\
\hline Other ${ }^{\mathrm{d}}$ & $1.87(0.46) \mathrm{A}$ & $0.59 \mathrm{a}$ & $0.59(0.14) \mathrm{B}$ & $4.67 \mathrm{ab}$ & $1.34(0.44) \mathrm{AB}$ & $5.39 \mathrm{~b}$ \\
\hline Oak (Quercus spp.) & $1.75(0.45) \mathrm{A}$ & $4.13 \mathrm{a}$ & $0.48(0.26) \mathrm{B}$ & $0.00 \mathrm{a}$ & $0.17(0.08) \mathrm{B}$ & $12.90 \mathrm{~b}$ \\
\hline Striped maple (Acer pennsylvanicum) & $1.43(0.37) \mathrm{A}$ & $3.10 \mathrm{a}$ & $1.06(0.52) \mathrm{A}$ & $1.58 \mathrm{~b}$ & $2.84(1.10) \mathrm{B}$ & $0.05 \mathrm{c}$ \\
\hline Sassafras (Sassafras albidum) & $0.87(0.25) \mathrm{A}$ & $14.01 \mathrm{a}$ & $0.51(0.28) \mathrm{AB}$ & $4.40 \mathrm{~b}$ & $0.08(0.06) \mathrm{B}$ & $28.57 \mathrm{a}$ \\
\hline American beech (Fagus grandifolia) & $0.77(0.30) \mathrm{AB}$ & $0.00 \mathrm{a}$ & $0.11(0.06) \mathrm{A}$ & $5.00 \mathrm{~b}$ & $1.34(0.40) \mathrm{B}$ & $10.74 \mathrm{~b}$ \\
\hline Red maple (Acer rubrum) & $0.63(0.11) \mathrm{A}$ & $13.23 \mathrm{a}$ & $0.68(0.16) \mathrm{A}$ & $6.56 \mathrm{~b}$ & $3.26(0.59) \mathrm{B}$ & $3.24 \mathrm{c}$ \\
\hline Sugar maple (Acer saccharum) & $0.56(0.12) \mathrm{A}$ & $12.87 \mathrm{a}$ & $0.51(0.15) \mathrm{A}$ & $6.52 \mathrm{~b}$ & $2.73(0.48) \mathrm{B}$ & $3.26 \mathrm{c}$ \\
\hline Blackgum (Nyssa sylvatica) & $0.27(0.15) \mathrm{A}$ & $4.17 \mathrm{a}$ & $0.05(0.03) \mathrm{A}$ & $22.22 \mathrm{ab}$ & $0.08(0.04) \mathrm{A}$ & $21.43 \mathrm{~b}$ \\
\hline Eastern hemlock (Tsuga canadensis) & $0.16(0.11) \mathrm{A}$ & $0.00 \mathrm{a}$ & $0.35(0.21) \mathrm{A}$ & $7.94 \mathrm{a}$ & $0.16(0.16) \mathrm{A}$ & $0.00 \mathrm{a}$ \\
\hline All species & $50.16(2.51) \mathrm{A}$ & $3.99 \mathrm{a}$ & 31.95 (1.81) B & $5.55 \mathrm{~b}$ & $18.93(1.44) \mathrm{C}$ & $3.32 \mathrm{a}$ \\
\hline
\end{tabular}

${ }^{\mathrm{a}} n=180$ plots in each type.

${ }^{\mathrm{b}}$ Available means in the same row followed by the same upper case letter were statistically similar $(P>.10)$.

${ }^{\mathrm{c}}$ Use percentages (PATB) in the same row followed by the same lower case letter were statistically similar $(P>.10)$

${ }^{\mathrm{d}}$ Includes cucumbertree (Magnolia acuminata), American basswood (Tilia americana), mountain magnolia (Magnolia fraseri), witch-hazel (Hamamelis virginiana), red spruce (Picea rubens), and wild grape (Vitis spp.)

TABLE 2: Percent of available twigs browsed (PATB), relative abundance (RA), relative use (RU), and white-tailed deer selection for woody browse species on the MeadWestvaco Wildlife and Ecosystem Research Forest, Randolph County, West Virginia during summer 2007.

\begin{tabular}{|c|c|c|c|c|}
\hline Species & PATB & RA & RU & Use $^{\mathrm{a}}$ \\
\hline Blackberry (Rubus spp.) & 5.12 & 34.37 & 40.40 & Greater \\
\hline Birch (Betula spp.) & 6.33 & 12.33 & 17.93 & Greater \\
\hline Pin cherry (Prunus pennsylvanica) & 7.07 & 4.04 & 6.57 & Greater \\
\hline Sassafras (Sassafras albidum) & 11.45 & 1.44 & 3.79 & Greater \\
\hline American Beech (Fagus grandifolia) & 6.73 & 2.20 & 3.40 & Greater \\
\hline Blackgum (Nyssa sylvatica) & 9.86 & 0.39 & 0.88 & Greater \\
\hline Sugar maple (Acer saccharum) & 5.12 & 3.76 & 5.30 & Equal \\
\hline Red maple (Acer rubrum) & 5.11 & 4.52 & 4.42 & Equal \\
\hline Oak (Quercus spp.) & 3.94 & 2.38 & 2.15 & Equal \\
\hline Eastern Hemlock (Tsuga canadensis) & 4.13 & 0.67 & 0.63 & Equal \\
\hline Black cherry (Prunus serotina) & 3.76 & 5.99 & 5.18 & Equal \\
\hline Greenbrier (Smilax spp.) & 1.39 & 15.08 & 4.80 & Less \\
\hline Yellow-poplar (Liriodendron tulipifera) & 0.29 & 3.77 & 0.25 & Less \\
\hline Striped maple (Acer pennsylvanicum) & 1.46 & 5.28 & 1.77 & Less \\
\hline Other & 2.92 & 3.77 & 2.53 & Less \\
\hline
\end{tabular}

${ }^{\mathrm{a}}$ Indicates RU values were significantly greater than, less than, or equal to RA values

reported in 2001 in both clearcut interior ( 50 twigs $/ 0.5 \mathrm{~m}^{2}$ versus 45 twigs $/ 0.5 \mathrm{~m}^{2}$ ) and mature forest (18.9 twigs $/ 0.5 \mathrm{~m}^{2}$ versus 10.2 twigs $/ 0.5 \mathrm{~m}^{2}$ ) plots, although we could not conduct formal statistical tests of these differences (see [19, Table 1]).
Our observed PATB rates were substantially lower than previously reported in both clearcut interior $(3.99 \%$ versus $15.5 \%)$ and mature forest (3.32\% versus $20.5 \%)$ plots (see [19, Table 1]). Our overall observed PATB across all plot types was $4.4 \%$, decreasing from previous 
estimates of $17.8 \%$ [19]. Again, formal statistical tests of these differences could not be conducted. This is consistent with additional studies showing a decrease in browsing rates from 2002 to 2004 during which deer were actively removed from the population for research purposes $[26,28]$.

\section{Discussion}

Previous studies of white-tailed deer browsing rates in the southern Appalachians [18] and coastal plain of South Carolina [21] documented overall summer browsing rates (PATB) of approximately $5 \%$ in areas of moderate whitetailed deer densities $\left(6-8 / \mathrm{km}^{2}\right)$, similar to our overall browsing rate of $4.4 \%$. Both Ford et al. [18] and Castleberry et al. [21] concluded that this level of browsing was not high enough to impede growth or establishment of forest vegetation. In contrast, Campbell et al. [19] reported browsing rates in excess of $17 \%$ on the MWERF in 2001 when white-tailed deer densities were estimated at $10 / \mathrm{km}^{2}$ [25] and concluded that this level of browsing would likely alter forest composition if it persisted. Miller et al. [28] reported that browsing rates in regenerating clearcuts on the MWERF decreased annually from 2001 to 2004 in part due to increases in the abundance of woody browse across the landscape as a result of increased timber harvest. This led Miller et al. [28] to suggest that a threshold of sufficient browse abundance to overcome herbivory may have been reached on the MWERF. However, Miller et al. [28] did not account for decreases in deer population density, which occurred concomitantly with increases in the amount of timber harvest on the MWERF. In a separate examination, Miller et al. [26] concluded that decreases in browsing rates within a small portion of the MWERF could be attributed to a small-scale experimental reduction in deer population size but failed to account for this across the entire study area. We observed slightly higher densities of woody browse in clearcut interior and mature forest plots than Campbell et al. [19], suggesting that the reduction in browsing rates across our study site may have led to increases in survival of young forest plants. However, the small magnitude of change in woody browse abundance ( $>10 \%$ increase) may be of little biological relevance. The higher browsing rates we observed along clearcut edge plots suggest that the effect of reduced browsing rates may be most prevalent within the interior of forest regeneration areas, and that future timber harvest strategies should attempt to reduce the amount of clearcut edge to insure limited browsing and to maximize initial regeneration, particularly when coupled with reduced deer population densities. However, previous research suggests that the browsing rates we observed along clearcut edges $(5.55 \%)$ are unlikely to have a substantial impact on the growth or survival of forest vegetation $[2,3$, $18,21]$.

Campbell et al. [19] suggested that low browsing rates of American beech would lead to a larger overstory component of this species and that high browsing rates of birch $(B$. allegheniensis, B. lenta) would lead to its decreased abundance in future stands. Conversely, Miller et al. [28] observed low browsing rates of birch species and a subsequent increase in its availability on the MWERF from 2001 to 2004, suggesting that birch could become an important overstory component in the future. We observed low browsing rates for both American beech and birch species $(<5 \%)$ but found relatively little American beech in our clearcut interior plots, indicating that future stands emanating from the forest regeneration sites we examined may have lower abundance of American beech than predicted by Campbell et al. [19] or suggested by the findings of Miller et al. [28], with the potential for a large birch component in future stands. The predictions of Campbell et al. [19] were based on the assumption that deer population density and browsing rates would remain at high levels. Moreover, variation in previous stand histories may have led to differences in initial species composition between clearcuts that we sampled and those sampled by Campbell et al. [19] and Miller et al. [28]. In addition to these factors, our results may have been slightly biased toward higher browsing rates because most of the clearcuts that were available for sampling during our study were on ridges or in higher elevation areas of the study site, which has been shown to affect browsing rates on the MWERF [19]. However, this would not affect our overall finding of a decrease in browsing rates. Variation in relay floristics or successional dynamics as a result of historic timber harvest strategies, species composition, or topographic location may have influenced browsing rates across the study area, although the extent of our sampling would likely mediate this effect [32]. McGill et al. [33] found that deer herbivory reduced the abundance of pin cherry (P. pennsylvanicus) seedlings on the MWERF, whereas pin cherry was relatively abundant in our plots despite being browsed in greater proportion than its availability. This contrast is likely the result of decreases in population density and increases in the amount of forest regeneration areas that combined to increase the amount of percapita browse available after the study of McGill et al. [33].

Our findings suggest that population density and browse abundance across the landscape can influence herbivory and forest regeneration patterns. Although we cannot infer a causal relationship between browsing rates and population density or timber harvest rates, our examination of browse use and abundance following substantial changes in deer population density and timber harvest rates is one of the few studies to attempt to explicitly link both factors simultaneously to changes in herbivory. We found that browsing rates at a population density of approximately 2 deer $/ \mathrm{km}^{2}$ were less than $1 / 3$ as high when population densities exceeded 10 deer $/ \mathrm{km}^{2}$. Differences between our results and the predictions of Campbell et al. [19] and Miller et al. [28] may indicate that using forest standbased (e.g., individual clearcut) studies of herbivory to predict landscape-level browsing patterns and effects on forest regeneration and structure may not be appropriate without explicitly accounting for confounding factors, such as population density and habitat structure. However, neither study $[19,28]$ considered the possibility of confounding changes in both population density and timber harvest rates. 
Discrepancies between our results and those of Campbell et al. [19] and Miller et al. [28] highlight the need for herbivory studies that account for temporal and spatial variation, particularly in highly dynamic systems.

It has been suggested that increasing timber harvest, thereby increasing the amount of available woody browse across the landscape, is a viable means of reducing browsing pressure to the point that growth and survival of forest vegetation is not impaired by deer $[17,18,28,34]$. However, increasing the amount of available forage could lead to increased productivity in deer herds in the future, offsetting the benefits of increased timber harvest if done in the absence of population control measures. It is not surprising then that the negative effects of deer herbivory are not as substantial in forest regeneration areas characterized by low deer densities regardless of the amount of timber harvest $[8,17]$. Deer densities less than $4 / \mathrm{km}^{2}$ have been suggested as necessary to ensure that diverse plant communities and healthy reproduction and regeneration of northern hardwood forest communities can persist, regardless of changes in timber harvest management [4]. We observed increases in the abundance of many commercially important species including oak, yellow-poplar, and black cherry since 2001 [19], supporting the theory that increasing timber harvest [28] along with deer population control [26] is a viable means of controlling herbivory, although it is impossible to determine if these increases in abundance were the direct result of changes in population density, amount of early successional habitat, or both. To our knowledge this is the first study to provide comparative data on browsing rates in an area experiencing both an increase in the amount of timber harvested and a reduction in deer density. Moreover, it supports the conclusions of previous researchers that reductions in population density and increases in the amount of early successional vegetation type can reduce deer browsing in forested landscapes. However, we recognize our inability to determine the relative contributions of deer population density and increased timber harvest rates to our observed decrease in herbivory rates. Although we could not account for confounding factors such as mast production, our post-hoc examination of deer herbivory suggests that a combination of increased timber harvest and decreased deer densities is likely to improve growth and survival of forest vegetation by reducing overall browsing rates. We caution against attributing these decreasing solely to changes in population density or timber harvest rates and suggest that large-scale experimental studies are needed to accurately assess the efficacy of these approaches for reducing deer browsing rates.

\section{Acknowledgments}

Funding and support for this research was provided by the MeadWestvaco Corporation, West Virginia Division of Natural Resources, and West Virginia University. C. Runner and A. Mynsberge assisted with data collection and plant identification. A. Mynsberge, R. Brooks, and two anonymous reviewers provided helpful comments on earlier versions of this paper.

\section{References}

[1] D. A. Marquis and R. Brenneman, "The impact of deer on forest vegetation in Pennsylvania," General Technical Report NE-65, US Forest Service, Northeastern Research Station, USDA, Broomall, Pa, USA, 1981.

[2] D. S. de Calesta, "Effect of white-tailed deer on songbirds within managed forests in Pennsylvania," Journal of Wildlife Management, vol. 58, no. 4, pp. 711-718, 1994.

[3] S. B. Horsley, S. L. Stout, and D. S. DeCalesta, "Whitetailed deer impact on the vegetation dynamics of a northern hardwood forest," Ecological Applications, vol. 13, no. 1, pp. 98-118, 2003.

[4] W. S. Alverson, D. M. Waller, and S. L. Solheim, "Forests to deer: edge effects in northern Wisconsin," Conservation Biology, vol. 2, no. 4, pp. 348-358, 1988.

[5] R. C. Anderson, "Height of white-flowered trillium (Trillium grandiflorum) as an index of deer browsing intensity," Ecological Applications, vol. 4, no. 1, pp. 104-109, 1994.

[6] D. J. Augustine and L. E. Frelich, "Effects of white-tailed deer on populations of an understory forb in fragmented deciduous forests," Conservation Biology, vol. 12, no. 5, pp. 995-1004, 1998.

[7] C. R. Rossell Jr., B. Gorsira, and S. Patch, "Effects of whitetailed deer on vegetation structure and woody seedling composition in three forest types on the Piedmont Plateau," Forest Ecology and Management, vol. 210, no. 1-3, pp. 415424, 2005.

[8] N. G. Tilghman, "Impacts of white-tailed deer on forest regeneration in northwestern Pennsylvania," Journal of Wildlife Management, vol. 53, no. 3, pp. 524-532, 1989.

[9] F. L. Russell and N. L. Fowler, "Effects of white-tailed deer on the population dynamics of acorns, seedlings and small saplings of Quercus buckleyi," Plant Ecology, vol. 173, no. 1, pp. 59-72, 2004.

[10] K. A. K. Stromayer and R. J. Warren, "Are overabundant deer herds in the eastern United States creating alternate stable states in forest plant communities?" Wildlife Society Bulletin, vol. 25, no. 2, pp. 227-234, 1997.

[11] W. S. Alverson and D. M. Waller, "Deer populations and the widespread failure of hemlock regeneration in northern forests," in The Science of Overabundance: Deer Ecology and Population Management, W. J. McShea, H. B. Underwood, and J. H. Rappole, Eds., pp. 280-297, Smithsonian Institution Press, Washington, DC, USA, 1997.

[12] R. C. Anderson and A. J. Katz, "Recovery of browsesensitive tree species following release from white-tailed deer Odocoileus virginianus Zimmerman browsing pressure," Biological Conservation, vol. 63, no. 3, pp. 203-208, 1993.

[13] W. J. McShea and J. H. Rappole, "Managing the abundance and diversity of breeding bird populations through manipulation of deer populations," Conservation Biology, vol. 14, no. 4, pp. 1161-1170, 2000.

[14] W. J. McShea, M. V. McDonald, G. E. Morton, R. Meier, and J. H. Rappole, "Long-term monitoring of Kentucky Warbler habitat selection," Auk, vol. 112, no. 2, pp. 375-381, 1995.

[15] S. Allombert, A. J. Gaston, and J.-L. Martin, "A natural experiment on the impact of overabundant deer on songbird populations," Biological Conservation, vol. 126, no. 1, pp. 1-13, 2005.

[16] S. Allombert, S. Stockton, and J.-L. Martin, "A natural experiment on the impact of overabundant deer on forest invertebrates," Conservation Biology, vol. 19, no. 6, pp. 19171929, 2005. 
[17] D. A. Marquis, R. L. Ernst, and S. L. Stout, "Prescribing silvicultural treatments in hardwood stands of the Alleghenies," General Technical Report NE-96, US Forest Service, Northeastern Research Station, USDA, Broomall, Pa, USA, 1981.

[18] W. M. Ford, A. S. Johnson, P. E. Hale, and J. M. Wentworth, "Availability and use of spring and summer woody browse by deer in clearcut and uncut forests of the Southern Appalachians," Southern Journal of Applied Forestry, vol. 17, no. 3, pp. 116-119, 1993.

[19] T. A. Campbell, B. R. Laseter, W. M. Ford, R. H. Odom, and K. V. Miller, "Abiotic factors influencing deer browsing in West Virginia," Northern Journal of Applied Forestry, vol. 23, no. 1, pp. 20-26, 2006.

[20] J. M. Wentworth, A. S. Johnson, P. E. Hale, and K. E. Kammermeyer, "Seasonal use of clearcuts and food plots by whitetailed deer in the Southern Appalachians," in Proceedings of the Southeastern Association of Fish and Wildlife Agencies, vol. 44, pp. 215-223, 1990.

[21] S. B. Castleberry, W. M. Ford, K. V. Miller, and W. P. Smith, "White-tailed deer browse preferences in a southern bottomland hardwood forest," Southern Journal of Applied Forestry, vol. 23, no. 2, pp. 78-82, 1999.

[22] N. M. Fenneman, Physiography of the Eastern United States, McGraw-Hill, New York, NY, USA, 1938.

[23] R. B. Clarkston, "Destruction of the upland forest by lumbering and fire," in Upland Forest of West Virginia, S. L. Stephenson, Ed., pp. 35-46, McClain Printing Company, Parsons, WVa, USA, 1993.

[24] S. T. Buckland, D. R. Anderson, K. P. Burnham, J. L. Laacke, D. L. Borchers, and L. Thomas, Introduction to Distance Sampling: Estimating Abundance of Biological Populations, Oxford University Press, Oxford, UK, 2001.

[25] C. A. Langdon, A comparison of white-tailed deer population estimation methods in West Virginia, M.Sc. thesis, West Virginia University, Morgantown, WVa, USA, 2001.

[26] B. F. Miller, T. A. Campbell, B. R. Laseter, W. M. Ford, and K. V. Miller, "Test of localized management for reducing deer browsing in forest regeneration areas," Journal of Wildlife Management, vol. 74, no. 3, pp. 370-378, 2010.

[27] J. K. Vreeland, D. R. Diefenbach, and B. D. Wallingford, "Survival rates, mortality causes, and habitats of Pennsylvania white-tailed deer fawns," Wildlife Society Bulletin, vol. 32, no. 2, pp. 542-553, 2004.

[28] B. F. Miller, T. A. Campbell, B. R. Laseter, W. M. Ford, and K. V. Miller, "White-tailed deer herbivory and timber harvesting rates: implications for regeneration success," Forest Ecology and Management, vol. 258, no. 7, pp. 1067-1072, 2009.

[29] T. A. Strole and R. C. Anderson, "White-tailed deer browsing: species preferences and implications for central Illinois forests," Natural Areas Journal, vol. 12, no. 3, pp. 139-144, 1992.

[30] J. H. Zar, Biostatistical Analysis, Prentice Hall, Upper Saddle River, NJ, USA, 1998.

[31] J. H. Sokal and F. J. Rohlf, Biometry, W. H. Freeman, New York, NY, USA, 1995.

[32] W. M. Ford, A. S. Johnson, P. E. Hale, and J. M. Wentworth, "Influences of forest type, stand age, and weather on deer weights and antler size in the Southern Appalachians," Southern Journal of Applied Forestry, vol. 21, no. 1, pp. 11-18, 1997.

[33] D. W. McGill, R. J. Collins, and W. P. Carson, "Response of pin cherry to fire, canopy disturbance, and deer herbivory on the Westvaco Wildlife and Ecosystem Research Forest," in Proceedings of the 13th Central Hardwood Forest Conference,
J. W. van Sambeek, J. O. Dawson, F. Ponder Jr., E. F. Loewenstein, and S. James, Eds., pp. 282-290, 2003, General Technical Report NC-234, US Forest Service, North Central Research Station, USA, St. Paul, Minn, 2003.

[34] C. Kalén, "Deer browsing and impact on forest development," Journal of Sustainable Forestry, vol. 21, no. 2-3, pp. 53-64, 2005. 

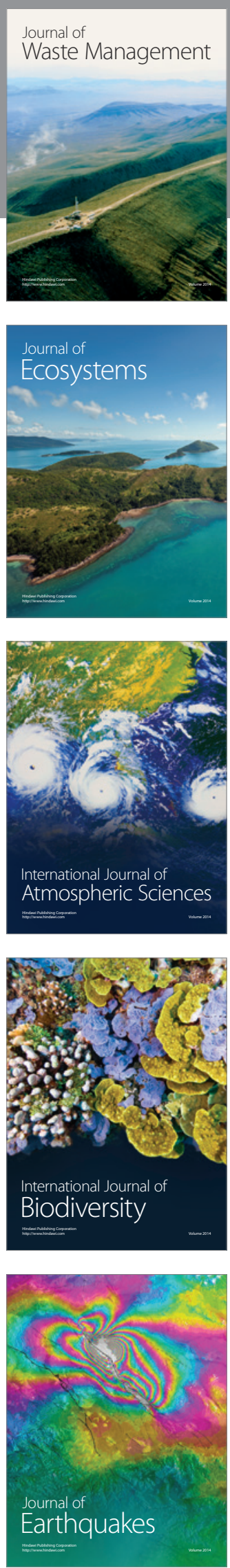
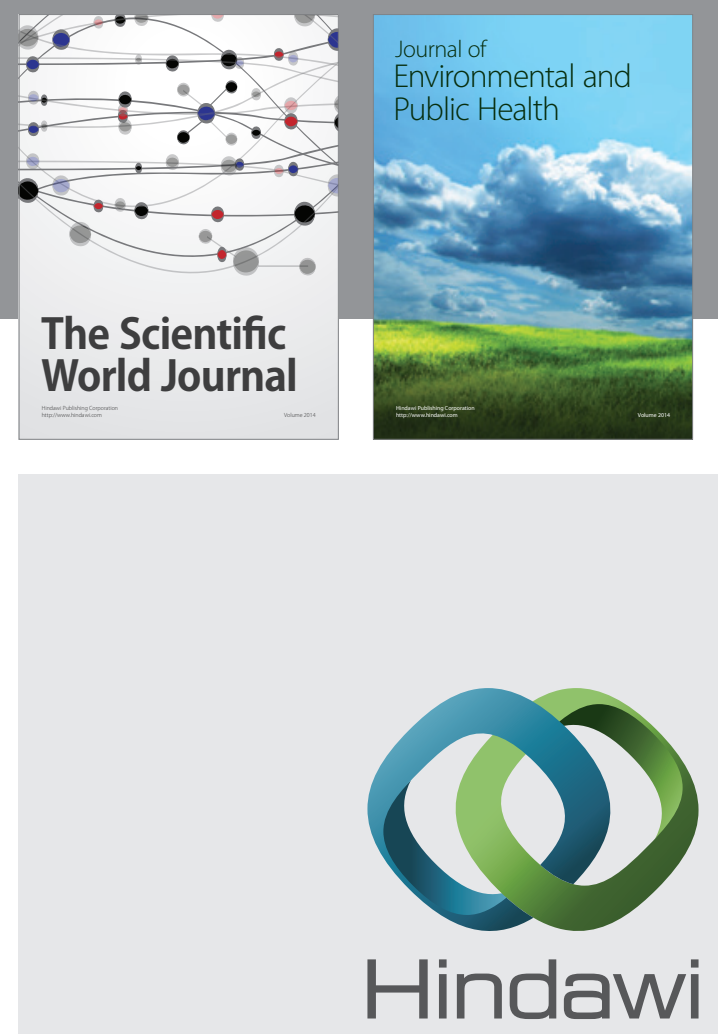

Submit your manuscripts at

http://www.hindawi.com
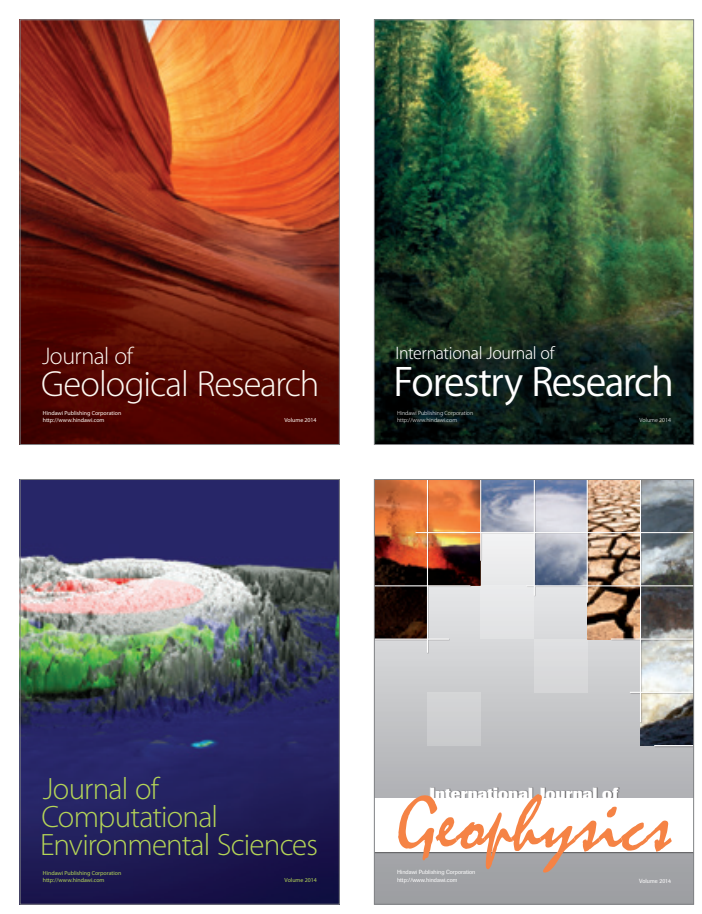
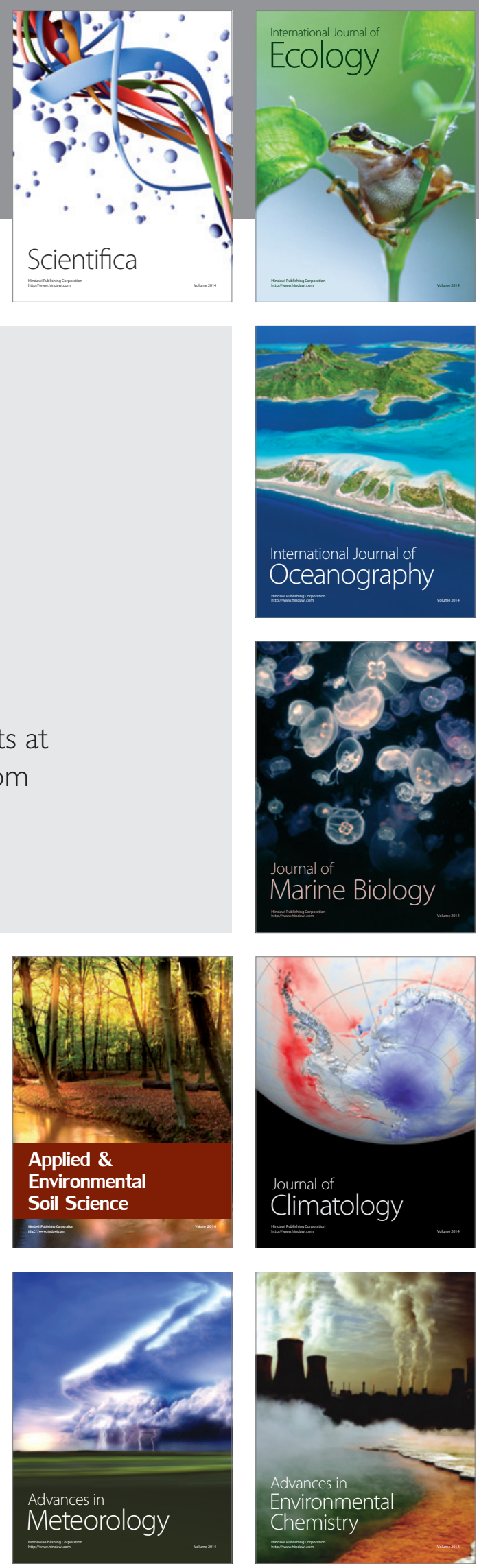